UNTAG Law Review (ULREV)

Volume 1, Issue 2, Nov 2017, PP 30-37

ISSN 2549-4910 (online) \& ISSN 2579-5279 (print)

http://jurnal.untagsmg.ac.id/indeks.php/ulrev/indeks

www.fakhukum.untagsmg.ac.id

\title{
ETHIC CYBER STRENGTHENING \\ ASCRIMINAL LAW POLICY FORMULATIONS IN RESPONSE CYBERPORN
}

\author{
Hervina Puspitosari, and Ashinta Sekar Bidari \\ Lecturer of Law Faculty University of Surakarta, \\ contact at email : hervinafh@gmail.com
}

\begin{abstract}
Cyber Porn is an act of using cyberspace to create, display, distribute, publish pornography and obscene material. Cyberspace with technology that carries pornography, so that pornography provides more feature-rich form of pornography, pornografipun experienced media translation and making pornography created with multi features. The lack of regulations on the provision of criminal sanctions for internet access service providers (ISP/Internet Service Provider)are not filtering out pornographic content so that they can be accessed internet users. Cyber ethics required for casting activity that is passed by internet users. Ideal criminal Legal policy of studies necessary legal substance of law reforms in the fight against cyberporn.
\end{abstract}

Keywords : Cyberporn, Internet Service, Pornography

\section{INTRODUCTION}

Technology known double-faced, on the one hand of great benefit to humans and as a sign of the progress of society, but on the other hand also can provide convenience and even extend global crime. Abuse or negative impact of advances in information technology through computerization and networking system known as "CyberCrime.As the development of Cyber Crime flourished and the termcrime CyberSex or CyberPorn.

Pornography is derived from Ancient Greek danger that pornc and graphos. Pornc means whore, specifically refers to the lowest class of prostitutes. At the time of Ancient Greece are not all prostitutes despised or low. Only pornenia prostitutes or women who are the least expensive, most unappreciated and no protection. They are like a sexual slave for the entire male population. Grapos means writing, sketches or drawings. Thus the meaning of pornography is writing, sketches or drawings of women as cheap class prostitute. Ade Armando in an article published by the Ministry of Women's Empowerment defines pornography as material presented in certain media that may or intended to arouse sexual desire or exploit sex audiences. The specific media that print and electronic media in audio or visual.

Cyber Porn is an act of using cyberspace to create, display, distribute, publish pornography and obscene material. Cyberspace with technology that carries pornography, so that

1 Sulistyowati Irianto, 2006 Perempuan dan Hukum, Menuju Hukum Yang Berperspektif Kesetaraan dan Keadilan, Yayasan Obor Indonesia, Jakarta,, pg. 299. 
pornography provides more feature-rich form of pornography, pornografipun experienced media translation and making pornography dikreasikan with multi features. ${ }^{2}$

To further improve the control and monitoring in an effort to prevent and combat cyber-porn it would require a joint effort between the government, law enforcement officials with the public, because without coordination jointly between the parties concerned will be difficult to eradicate the spread of cyber porn as one of the negative impact misuse of technology. Society began to feel the effects and consequences of poor significantly, even within the level of malicious threats and crimes against the interests of society and lead to moral degradation.

\section{The problem formulation}

The formulation of the problem that researchers take is as follows:

1. How does the current criminal law policy in an effort to tackle cyberporn?

2. Why the current criminal law policy in an effort to tackle cyber porn Effective yet?

3. How to model cyber ethics in strengthening the criminal law policy formulation for the reduction of cyberporn?

\section{Research Methods}

This study is a legal specification as an empirical legal research. Legal research Empirical or with other terms commonly used sociological and legal research can / usually also referred to as field research. Empirical legal research or non-doctrinal research is research in the form of empirical studies to find theories about the process and about the workings of law in society. ${ }^{3}$ .Specifications research emphasis on the science of law and focuses on secondary data collection which is the primary legal materials, secondary, and tertiary. ${ }^{4}$

\section{Discussion}

\section{Criminal Law Policy In Effort to Tackle Cyber Porn}

\section{Development Dynamics Cyberporn in Indonesia}

Internet is a space of information and communication that promise through the boundaries between countries and accelerate the dissemination and exchange of knowledge and ideas among scientists and scholars around the world. Internet brings us to a room or a new world that is created is called Cyberspace. This new world many give easiness for the development of human civilization, where the residents can connect with anyone, anywhere and anytime. Many people use this technology to the interests of the public business (e-commerce), even utilization has reached the needs of private and cause dependence itself for used. Cyberspace technology can facilitate human life, namely the ease of use of internet facilities. Simply by typing a series of words through search engines (keyword) is desired, it will be easily obtained data and information presented by the various sites.

But the reality of this impact further and serious, because there will be a proliferation of new modes of transacting and communicating. One is cyberporn (pornography cyberspace) pornography on the Internet can not be avoided because the information flow and communication increasingly sophisticated. This is due to sex is a commodity that can carry a large enough profit in the business, especially through e-commerce services. Pornography

2 Feri Sulianta, 2010 Cyber Porn Bisnis atau Kriminal, Elex Media Komputindo, Jakarta, ,pg 3 - 4

3 Bambang Sunggono. 2003 Metodologi Penelitian Hukum. Raja Grafindo Persada, Jakarta, ,pg. 42

4 Soerjono Soekanto, Sri Mamudji. 2006. Penelitian Hukum Normatif (Suatu Tinjauan Singkat). Ctk. Pertama, Jakarta: PT. Raja Grafindo Persada .pg. 14-15 
which extended to the virtual world can be easily accessed by anyone, regardless of age, sex, education level, and social stratification.

Etymologically, pornography comes from two syllables, namely pornos and pornography. Pornos, means an act that is immoral (in matters relating to sex), or actions that are indecent or obscene. Tomographic are pictures or writing, which in its broadest sense means that the contents or show or describe something that is immoral or offensive sense of morality in society. The development of technology has provided space and opportunity for the dissemination of pornography, the computer can function duplicate files into VCD pornographic contents, then sold or rented to people who are interested. The Internet is one medium / media are often used to conduct business transactions, the dissemination of science and technology, dissemination of news and information, on the other hand is also used to disseminate pornography in the form of electronic information in the form of pictures, photographs, moving images (video), and other forms.

Interactive global communications network via internet relay chat facility (chattiny) can be used to disseminate information about stories or pornographic pictures (for both the dark side and the bright side of pornography) or also called cybersex. Cyberspace itself is a psychological space, psychological space turned out to open up opportunities for criminals, not to mention the presenters and the netters who exchanged collection of images or text that are pornographic. It is no doubt that the current Internet users are mostly young people, so the presence of cyberporn is an entertainment in itself, let alone the images presented are pictures of people who have been known in the community.

Cybernation process that raises hopes will ease, pleasure and opportunity that was not always the case because in cyberspace there is also a dark side we need to consider, as declared by Neill Barrett and Mark D. Rasch that the Internet has a dark side, as a means of supporting crime, where $80 \%$ of the picture on the internet is a pornographic image. Cyberporn or cybersex is one of the negative sides of their information technology. This is due to sex is a commodity that can carry a large enough profit in the business, especially through ecommerce services. Pornography which extended to the virtual world can be easily accessed by anyone, regardless of age, sex, education level, and social stratification. In addition, the ease and convenience in transacting online sex, childbirth and privilege satisfaction of its own, which is often argued to no much harm, due to anxiety and negative effects are not directly felt.

Pornography is relative, meaning that depending on space, time, place, and the people and culture of a nation. Even in a nation's own environment, variations pornography sense that, for example, between tribes Aceh and Bali, Minahasa and Bugis occur once a striking difference. Traditional pornography is usually done through the old media such as books, magazines, films and videotapes. The presence of the Internet and cyberspace given its own color in the problems of pornography. Pornography on the Internet relating to the content or the content of sites presented to accesses, so the Convention on Cybercrime of the European Union in the category of pornography categorize Content-related offenses contained in Title 3, article 9. There are at least four opinions relating to pornography as inferred by Jonathan Blumen, namely: "Pornography is bad Because it is violence and oppression (Catharine Mackinnon) Pornography must be tolerated for free speech reasons (Nadine Strossen) Pornography is good, liberating, Allows us to grow as sexual beings (Wendy McElroy) Pornography is absolutely bad by religious or other Commandment rule Arising from a morality of prohition".

Interactive global communications network via internet relay chat facility can be used to disseminate information about stories or pornographic pictures (for both the dark side and the 
bright side of pornography) or also called cybersex. There are two forms of cybersex in a chat room, which is mediated interactive Computer masturbation in real time and Computer mediated telling of interactive sexual stories (in real time) with the intent of arousal.

Meanwhile, according to Law Number 44 Year 2008 on Pornography, pornography is: drawings, sketches, illustrations, photographs, text, voice, sound, moving pictures, animation, cartoons, conversation, gestures, or forms other messages through various forms of communication media and / or performing in public, which contains obscenity or sexual exploitation that violate the moral norms in society.

Further stated that the regulation of pornography berasaskan on God, respect for human dignity, diversity, legal certainty, non-discrimination, and protection of citizens.

According to LIPI researcher, Romi Satria Wahono stated that every second there are 28258 people view porn sites, every second 372 Internet users type in certain keywords in search engines to search for pornographic content, and the number of pages of pornography sites in the world reached 420 million. The spread of pornography in cyberspace is closely connected with the industry of pornography that crosses borders between countries. The US is the largest contributor to the State $89 \%$ of porn sites in the world. Followed by Germany, Britain, Australia, Japan and the Netherlands following behind. although American contributor to the world's biggest porn site, was only ranked fourth in the number of income (revenue) of the porn industry in the world. The winner is precisely China, followed by South Korea and Japan. Total annual income of the porn industry in the world is around 97 billion USD, equivalent to a total income of large American companies are: Microsoft, Google, Amazon, eBay, Yahoo !, Apple, Netflix and EarthLink. It shows how powerful the porn industry in the world. This is somewhat related, one article in CNET in 1999 states that: Pornography online is ecommerce product that has consistently ranked first in business on the Internet. From the data on Internet pornography above, which is quite astonishing is that the receiver turns connoisseurs and negative effects of Internet pornography industry is not the producer countries, but even smaller countries and developing as consumers. We can see from the trend of the search request with the three keywords, namely xxx, porn and sex, all dominated by small or developing countries such as Pakistan, South Africa, India, Bolivia, Turkey, and Indonesia.

According to Dr. Mary Anne Layden of the researchers from the University of Pennsylvania, cyberporn have an impact that is not good, namely, rising crime. He said, "I have been providing assistance to the perpetrators and victims of sexual violence for 13 years. And I've never handled one case that is not caused by pornography. Pornography triggers aggression and eventually lead a person to commit a crime. "Second, a risk to the psychological and educational. According to VB Cline, a riserter psychosocial problems and pornography, said there are four stages of the development of sexual addiction to the consumer of pornography: (1) addiction or addiction, (2) escalation, namely: improving the quality of addiction that is behavior that increasingly diverge, (3) Desentisisasi, namely: increasing depletion of sensitivity, and (4) Acting Out, namely: pornography addicts started practicing. Third, the health risks. According to the Health Division of ASA Indonesia Dewi Inong irara, a specialist in skin and venereal diseases, explained the health risks caused by the Infectious Diseases Sexual (STD) caused by pornography is infection genitals, complications, disease genitals in chronic, genital cancer, infectious baby in the womb, and HIV / AIDS. Fourth, the cultural risks (shift values). This time can already be seen clearly as a result of the porn industry, a lot of cultural values in society are not ignored anymore, like the night life world that is identical to the places of prostitution and pornography offenders increased. 
To prevent and counter the proliferation of porn sites accessed, then the criminal law can be used to as a tool though is merely symptomatic treatment. Policies or efforts to combat crime is essentially an integral part of efforts to protect the public (social defense) and efforts to achieve public welfare (social welfare). Therefore it can be said that the ultimate goal or primary purpose of criminal politics is "the protection of society to achieve the welfare of the community". Crime prevention efforts need to be taken with a policy approach which includes the integration (integralitas) between political crime and social and political integration of efforts to combat crime with penal and non-penal. Crime prevention efforts are integral implies also that the whole society with its potential to be seen as part of a political criminal.

\section{Arrangements Cyber Porn in Indonesia}

Indonesia has some of the rules relating to cyberporn. For example, the Code of Penal (Penal Code), the Telecommunications Act, the Law on Information and Electronic Transactions (ITE).

\section{a) The Code of Penal (Penal Code)}

of the Criminal Code that is used in Indonesa today is a translation of the Wetboek van Strafrecht (WvS) imposed by Act No. 1 of 1946 on the Criminal Code for the whole territory of the Republic of Indonesia. Based on the provisions stipulated in the Criminal Code related to prostitution are listed in the following terms:

The forms of the crime of pornography in the Criminal Code are grouped into three:

1) A criminal offense in the form of sexually explicit,

2) Criminal acts in the form of pornography,

3) The crime of pornography as livelihood

Cyber pornography perhaps can be defined as the spread of pornographic content via the internet. Dissemination of pornographic content over the Internet is not specifically regulated in the Criminal Code. The Criminal Code is not known term / evils of pornography. However, there is the Criminal Code that can be worn for this act, namely Article 282 of the Criminal Code on crimes against decency.

"Whoever distributes, or puts up a writing, images or objects that have known it is in violation of decency, or whoever with the intention to broadcast, shown or pasted in public, make writing, picture or the object, put it in the country, forward, take it out of the country, or have inventory, or whoever openly or by circulating a letter without being asked, offered or show as can be obtained, punishable by a maximum imprisonment of one year and six months, or a fine of four thousand five hundred rupiah

b) Act oF No. 36 of 1999 on Telecommunications

on 8 September 1999 passed Act No. 36 of 1999 on Telecommunications. Background or sociological foundation of this law is that the impact of globalization and the development of telecommunications technology has resulted in a very rapid fundamental changes in the organization and the perspective of telecommunications; Article 21, which reads "Telecommunications operator is prohibited from conducting business telecommunications operation contrary to the public interest, ethics, security and public order".

c) Law Number 19 Year 2016 on the Amendment of Act No. 11 of 2008 on Information and Electronic Transactions 
Article 27 paragraph 1 of Law ITE "Any person intentionally and without right to distribute and / or transmitting and / or make the inaccessibility of Electronic Information and / or electronic documents that have a charge of violating decency.

"Elucidationof the article:

Paragraph (1)

The definition of" distributing "is sending and / or disseminate electronic information and / or electronic documents to many people or various parties through the Electronic System.

What is meant by "transmit" is to send the Electronic Information and / or electronic document, addressed to the other party through the Electronic System. What is meant by "making accessible" is all the other acts in addition to distributing and transmitting via the Electronic System which causes the Electronic Information and / or Electronic Documents can know the other party or the public.

d) Law Number 44 Year 2008 on Pornography

Act which expressly regulate the pornography is Law No. 44 Year 2008 on Pornography (Pornography Act). Understanding pornography in accordance with article 1 paragraph 1 of the Law on Pornography is:

"... drawings, sketches, illustrations, photographs, text, voice, sound, moving pictures, animation, cartoons, conversation, gestures, or forms other messages through various forms of communication media and / or show in public, which contains obscenity or sexual exploitation that violate the moral norms of society."the

prohibition of the dissemination of pornographic content, including via the internet, set out in article 4 paragraph (1) pornography Act, namely;

"Every person is prohibited to produce, produce, reproduce, copy, distribute, broadcast, importing, exporting, offering, reselling, renting or providing explicit pornography that includes:

a. cooperation, including aberrant mating;

b. sexual violence;

c. masturbation;

d. nudity or nudity an impressive display;

e. genitals; or

f. child pornography."

Violation of Article 4 paragraph (1) of the Law on Pornography threatened with imprisonment of minimum six months and maximum of 12 years and / or fined at least Rp250 million and at most 6 billion (article 29 of the Law on Pornography).

Article 10 of Law Number 44 Year 2008 on Pornography "Every person is prohibited from exposing themselves or others in the show or in public that depicts nudity, sexual exploitation, mating, or other pornographic contents".

Pornography Law Article 44 states that when the Act comes into force, all laws and regulations governing or relating to the crime of pornography shall remain valid to the contrary in this Act. 


\section{Factors Contributing to the Criminal Law Policy In Effort to Tackle Cyber Porn Not Effective}

Internet technology led to a new civilization, where the displacement of the reality of life of real activity to the activity of the virtual (virtual) termed cyberspace. Developments in information technology are not only able to create a global world, but also has developed the space for a new life for the people, that is the life of the virtual community(cybercommunity). Cybercommunity is a life of human society can not be directly sensed by human senses, but can be felt and seen as a reality. In the virtual community, the method of life not much different from real life, there is a social process, social interaction, social control, communications, building a culture, even the system development and other crimes.

Internet provides various facilities in many aspects of human life as it has changed the distance and time become infinite. Their chat, e-mail and web-cam is a solution of the problems of long-distance communication that use the phone at a high cost.

\section{Model Cyber Ethics In Criminal Law Policy Formulation Strengthening Efforts For Cyber Porn}

Cyber ethics is a set of unwritten rules that aim fellow user gave the universal value of information technology. The absence of clear limits physically as well as the extent of the use of IT in various fields to make everyone who uses information technology are expected to abide by cyber the existingethics. ${ }^{5}$

Ethics is the science of what is good and what is bad as well as the rights and obligations (morals) Ethics in the surf usually called cyber ethics (cyber ethics). Cyber ethics is an unwritten rule known in the IT world. A values are agreed to be followed in which user interaction technology, particularly information technology. The absence of clear limits physically as well as the extent of the use of IT in various fields to make everyone who uses information technology are expected to abide by the existing cyber ethics. Cyber ethics bring new opportunities in education, business, government service with their Internet presence. Thus developed netiquette / etiquette in technology is one of the ethical reference in communicating using the Internet, based on the IETF(theInternet Engineering Task Force), which sets RFC (netiquetteguidelies in a request forcomments). ${ }^{6}$

The human propensity to behave not be separated from instinct and feelings in him. According to experts soul Sciences instinct had indeed been brought humans from birth. The desire arising from instinct was a "boost"(drive), as well as sexual desire, lust mixed with other species, appetite, lust sustain lives hang lust, desire to relate to others, and so on. Encouragement uncontrolled appetite may lead humans behave in a criminal act. In addition to the human instinct also have the feeling that consciousness arises from within man as a reasonable mind healthy, can distinguish between good and bad, joy and compassion look happy and hard. Altruistic human nature makes it more wear feeling of instinct. His religion knowledge, relationships and experiences, causing it to soulful. If he saw someone being treated unfairly, then at least he felt pity and feelings will arise to try to help, prevent or protect from acts of injustice, or simply counseled patience. ${ }^{7}$ Although the field of law must be distinguished from the moral sphere but the law can not maintain its legitimacy if apart from

5 http://jastroklasik.blogspot.co.id/2013/04/cyber-ethic-dan-contoh-kasus.html

6 http://ul501.ilearning.me/2015/05/04/atrikel-tentang-isu-isu-cyber-ethics/,

7 Hilman Hadikusuma, 1986 Legal Anthropology Indonesia, Alumni, Bandung, , pg. , 6-7 
the basic demands of fair form of life with human dignity.

Sometimes due to human apperception change due to see its natural environment changes, then the resulting feeling that wants a change also in applying the rule-indigenous. Thus the human being trying to change the old system of social control with the new system of social control. $^{8}$

\section{Conclusion}

The absence of regulations on the provision of criminal sanctions for internet access service providers (ISP /Internet Service Provider)are not filtering out pornographic content so that they can be accessed internet users. Cyber ethics required for casting activity that is passed by internet users. Legal policy ideal criminal laws required the substance of the study of law reforms in the fight against cyberporn.

\section{Suggestions}

1. importance of public awareness in internet use positive.

2. Provision filter for internet service providers so that the site cyberporn sites already blocked and can not be enjoyed by users of internet services.

\section{References}

Abdulkadir Muhammad. 2004. Hukum dan Penelitian Hukum.Cet. 1. Bandung: PT. Citra Aditya Bakti

Bambang Sunggono. 2003. Metodologi Penelitian Hukum. Raja Grafindo Persada, Jakarta

Feri Sulianta. 2010. Cyber Porn Bisnis atau Kriminal, Elex Media Komputindo, Jakarta

Hilman Hadikusuma. 1986. Antropologi Hukum Indonesia, Alumni, Bandung

Moh. Kemal Darmawan. 1994. "Strategi Pencegahan Kejahatan", Citra Bakti, Bandung

Moeljatno. 1990.. Kitab Undang-undang Hukum Pidana Jakarta: Bina Aksara

P.A.F. Lamintang. 1990. Hukum Pidana Indonesia, Bandung: Sinar Baru

Peter Mahmud Marzuki. 2008.Penelitian Hukum.Cet 2. Jakarta: Kencana

Sulistyowati Irianto. 2006. Perempuan dan Hukum, Menuju Hukum Yang Berperspektif Kesetaraan dan Keadilan, Yayasan Obor Indonesia, Jakarta

Soerjono Soekanto, Sri Mamudji. 2006. Penelitian Hukum Normatif (Suatu Tinjauan Singkat). Jakarta: PT. Raja Grafindo Persada

Sulistyowati Irianto. 2006. Perempuan dan Hukum, Menuju Hukum Yang Berperspektif Kesetaraan dan Keadilan, Yayasan Obor Indonesia, Jakarta

http://jastroklasik.blogspot.co.id/2013/04/cyber-ethic-dan-contoh-kasus.html

http://ul501.ilearning.me/2015/05/04/atrikel-tentang-isu-isu-cyber-ethics/ 